\title{
Implementation of Eco-Industrial Park for Effectual Establishment of Circular Economy in Russia
}

\author{
Ipsita Saha*(**)†, Tatiana S. Smirnova***(****) and Vladimir A. Maryev**** \\ *Department of Mechanical Engineering, Jadavpur University, India \\ **Department of Computer Science \& Engineering, Guru Nanak Institute of Technology, India \\ ***Gubkin Russian State University of Oil and Gas (National Research University), Moscow region, Russian Federation \\ ****Environmental Industrial Policy Center - Federal Autonomous Institution, Moscow Region, Russian Federation \\ $\dagger$ Corresponding author: ipsita.saha49@gmail.com
}

Nat. Env. \& Poll. Tech.

Website: www.neptjournal.com

Received: 07-07-2021

Revised: 20-09-2021

Accepted: 01-10-2021

\section{Key Words:}

Eco-industrial park (EIP) Innovative infrastructure Industrial symbiosis

Waste management

Secondary resources

Sustainable development

Resource efficiency

\section{ABSTRACT}

In recent years, waste management has become a major concern in Russian cities. This can be addressed through the circular economy. Developing Eco-Industrial Parks (EIP) can be considered an innovative infrastructure of a circular economy. EIP is based upon the principles of industrial symbiosis involving the exchange of material and energy flows, sharing of infrastructural facilities, and provision of municipal utility and other services. Researchers have found that most industrial symbiotic interconnections originated spontaneously, the main driver being the increasing commercial benefits of such interchange. Still, the authors were able to identify pre-designed EIP through their examination of global practices. This paper proposes a five-stage methodological approach to EIP organization. This methodology was applied to create a model of an EIP in the Voronezh Region, one of the fastest developing regions in Russia. Implementation of this model is intended to help solve a set of environmental, economic, and social problems of a region. The approach to creating EIPs described in this study can be used in other places to improve resource efficiency and reduce waste disposal. Because Russia's garbage disposal rate currently exceeds $90 \%$ per year, this is one of the country's top sustainable development priorities.

\section{INTRODUCTION}

Innovative infrastructure based on a circular economy is a concern of many cities around the world. This demand is mainly driven by the lack of raw materials, an increasing volume of hazardous waste, intensifying unplanned landfills, and the lack of energy resources. Disposal of waste is a problem in many cities of Russia and a solution is immediately required towards the establishment of energy-efficient infrastructure. Developing a circular economy for industrial processes will reduce resource consumption and eliminate unauthorized landfills and dumps. EIP in Russia integrates the concept of circular economy, which is crucial for the sustainable development of the country (Zhou et al. 2017, Pakhomova et al. 2017).

The basic premise of ensuring an ecosystem's sustainability is to keep its constituents in a closed loop. Despite the fact that the entire biosphere is enveloped in a circle of intense global currents and changes, these currents and changes are almost perfectly balanced; in other words, they are looped. Everything that a living organism has produced, including itself, is consumed by organisms of other species, chain-wise. These processes are cyclical and do not result in the creation of "surplus" matter due to the use of solar energy.
Metabolic (within an organism) and physical (natural circuit of matter) cycles in the biosphere ensure chemical and physical continuity of the environment. The law of equilibrium of cycles may be termed the "principle of cyclical circularity", or "circularity principle". Looped metabolic and physical cycles help to maintain the continuity of chemical and physical properties of the biosphere, which is called sustainability (Mashukova 2016, Skobelev 2020).

Based on various research gaps and research questions the following research objective have been set for the study, objective 1: Analyze the possibility of organizing an industrial system by analogy with the natural system through the creation of eco-industrial parks, objective 2: Develop an algorithm for organizing eco-industrial parks and objective 3: To put the developed algorithm to the test on a real-world problem in one of Russia's regions. The project's major goal is to create a mechanism for putting a circular economy into practice in eco-industrial parks by closing resource cycles. For Russia's sustainable development, improving resource efficiency and decreasing waste disposal at landfills are top priorities.

The paper presents a methodological approach towards the organization of EIP, with five main stages: 
Step 1 - Assessment of the current situation in the field of waste and secondary resources management in the region

Step 2 - Collecting the main flows directed to the EIP

Step 3 - Defining the object composition of the EIP and the list of technological solutions

Step 4 - Selection of a land area for EIP location

Step 5 - Defining the EIP performance indicators

This is an aggregative method, but it does not allow for the formulation of a comprehensive concept for the creation of eco-industrial parks. Each level can be detailed in the future based on the unique design conditions of eco-industrial parks.

This principle of natural ecosystems organization is the foundation of the circular economy concept (Tyrganova \& Makhashkeeva 2014). Similarly, to a natural ecosystem, the industrial and utility system may be regarded as a spatially defined aggregate of production components (cells), including production sites, facilities, factories, etc., and natural objects, all integrated with material, energy, and information interconnections (Smirnova et al. 2018). Within such a system waste generation is the result of the production processes. Waste management, existing in such systems, requires the collection, transportation, recycling, decontamination, or landfilling (Ayres \& Simonis 1994). Material and energy flows are transported between components (objects) of the industrial realm and the environment in municipal/industrial ecosystems, just as they are in natural ecosystems. There is an informal interaction between these objects.

The analogy between natural and municipal/industrial ecosystems can be described as "industrial symbiosis". Industrial symbiosis, as a part of the new area of the industrial ecology, implies combining of the material and energy flows via local and regional economics. This symbiosis draws the attention of traditionally autonomous industries to collaborate to achieve a competitive advantage in the physical exchange of materials, energy, and water (Fischer-Kowalski 1998). The core elements of the industrial symbiosis are active collaboration and symbiotic opportunities ensured by the geographical proximity of industrial enterprises (Albino et al. 2016).
For optimal implementation, the concept of creating an eco-industrial park should be based on an interdisciplinary approach. Several terminologies and definitions are used by organizations to refer to EIPs and similar related concepts. Fig. 1 presents combinations of commonly used terms relating to EIPs. As per World Bank 2021 International Framework for Eco-Industrial Parks, broadly, EIPs can be defined as, "managed industrial areas that promote cross-industry and community collaboration for common benefits related to economic, social and environmental performance". The concept of EIP has evolved to address additional and interrelated aspects, including, resource-efficient and cleaner production, climate change, pollution, industrial symbiosis, social standards, shared infrastructure, and management of risks and shared resources at higher echelon, land, and ecosystem services.

In worldwide practice, such interconnections have been evolved into Eco-Industrial Parks (EIP). The generally accepted definition of EIPs is currently based on the wording by Ernest Lowe published in 2001 in the "Eco-Industrial Handbook" prepared with the assistance of the Asian Development Bank - "An Eco-Industrial Park is a community of manufacturing and service businesses seeking enhanced environmental and economic performance through collaboration in managing environmental and resources issues including energy, water, and materials. By working together, the community of businesses seeks a collective benefit that is greater than the sum of the individual benefits each company would have realized if it optimized its individual interests" (Ernest 1995).

However, other definitions exist, emphasizing specific features and components of an EIP. Below there are some examples of them.

According to Smirnova et al. (2019), the term eco-industrial park is used to define both eco-industrial parks and eco-innovative areas combining residential and industrial activities, such as eco-cities or eco-industrial zones. Eco-innovation parks are designed with the environment in mind (e.g., piloting installations and processes, designing new goods) and actively work with research and development institutions.

\begin{tabular}{|c|c|c|}
\hline $\begin{array}{c}\text { Eco } \\
\text { Sustainable } \\
\text { Low Carbon } \\
\text { Green } \\
\text { Circular }\end{array}$ & $\begin{array}{c}\text { Industrial } \\
\text { (Special) Economic } \\
\text { Technological } \\
\text { Investment } \\
\text { Manufacturing }\end{array}$ & $\begin{array}{l}\text { Park } \\
\text { Zone } \\
\text { Area } \\
\text { Cluster } \\
\text { Estate }\end{array}$ \\
\hline
\end{tabular}

Fig. 1: Combinations of terms used internationally in relation to Eco-Industrial Parks (Source: World Bank 2021) 
Côté and Cohen-Rosenthal present the following definitions (Côté \& Cohen-Rosenthal 1998, Coté \& Hall 1995), "An Eco-Industrial Park is a community of businesses aiming at the improvement of their environmental and economic performance through co-operation inefficiently sharing resources including efficient consumption of energy, water, and materials. An EIP is created to improve the economy of its participants while minimizing their environmental impact. Components of this approach involve a new or redefined design of parking infrastructure and installations, prevention of pollution, increasing energy efficiency, and other areas of collaboration between the companies in and EIP. Such form of cooperation may be defined as an industrial ecosystem."

"An Eco-Industrial Park is an industrial system which conserves natural and economic resources; reduces production, material, energy, insurance, and treatments costs and liabilities; improves operating efficiency, quality, worker health, and public image; and provides opportunities for income generation from use and sale of wasted materials".

In their publications Chertow (2007), Smirnova et al. (2019), and Côté and Cohen-Rosenthal (1998), the authors claim that the key factor of EIP operation is establishing material and energy flows between businesses both on the local and regional economy levels. The key element of all the above definitions of the concept of "eco-industrial park" is the organization of "closed cycles of materials" between enterprises in EIPs. Such exchanges of material and energy flows are called industrial symbiosis.

As a result, EIPs apply a set of industrial ecology system components, presenting another definition of an EIP as "an industrial unity of businesses aimed at more efficient use of natural resources, also via industrial symbiosis" (Kiseleva et al. 2018).

By physically exchanging materials, energy, water, and by-products, industrial symbiosis encourages industries that operate separately to come together in sharing material and energy flows in areas with essential and technological options, gaining a competitive economic and environmental edge for all participants (Neves et al. 2016). New "unexpected" connections between various facilities operating in different production (among others) industrial areas may appear in EIPs thanks to the geographical proximity of such facilities. For instance, some authors define an EIP as "a set of manufacturing and service businesses located within one site and employing the same infrastructure" (Hein et al. 2016).

EIPs can be developed via two approaches, the first one is based on self-organization of companies into an EIP and the second one could be based on an analysis of the production processes of the potential EIP participants as well as local/ regional material and energy flows, implying a dedicated design of an EIP.

The second approach is more holistic. Owners of business organizations may have an interest in forming (participating in) an EIP as soon as they discover the prospects for maximizing operational efficiency through symbiosis (Alejandro et al. 2018).

Table 1 demonstrates a few examples of eco-industrial parks with the main benefits that have been achieved in their operation.

Designing the organization of an EIP requires methodological approaches and template technical and administrative solutions. Many authors proposed different approaches for this task (Chew et al. 2017, Tiejun 2010, Park \& Behera 2014, Leeuwen et al. 2003). Still, the analysis of the solutions proposed by Chew et al. (2017), Tiejun (2010), Park and Behera (2014), and Leeuwen (2003) indicates the need to consider national specifics of economics in the regions where the EIP should be established. This paper attempts to take into account such specific features.

The assessment of material flows that can be directed to the eco-industrial park is the general step of the analyzed approaches to the organization of EIPs and the established methodology. At the same time, in addition to identifying material flows, an important stage in the established technique is determining the location of the eco-industrial park, taking into account the possibilities of the subsequent sale of its products.

\section{MATERIALS AND METHODS}

The study is divided into two parts.

The first part describes the developed methodology for organizing eco-industrial parks. The creation of EIPs is a multi-step process that starts with an analysis of the current situation "before the organization of an EIP" to an assessment of its operation. The key steps in the process for organizing Eco-Industrial Parks were formulated after an analysis of socioeconomic factors and environmental indicators in the regions of potential EIP locations. The EIP guide scheme is shown in Fig. 2.

In the second part of the study, the developed approach was applied to create a model of an Eco-Industrial Park in the Voronezh Region, one of the developing regions of the Russian Federation.

The article is based on the analysis of literature sources, official regional data, and case studies of the authors. 


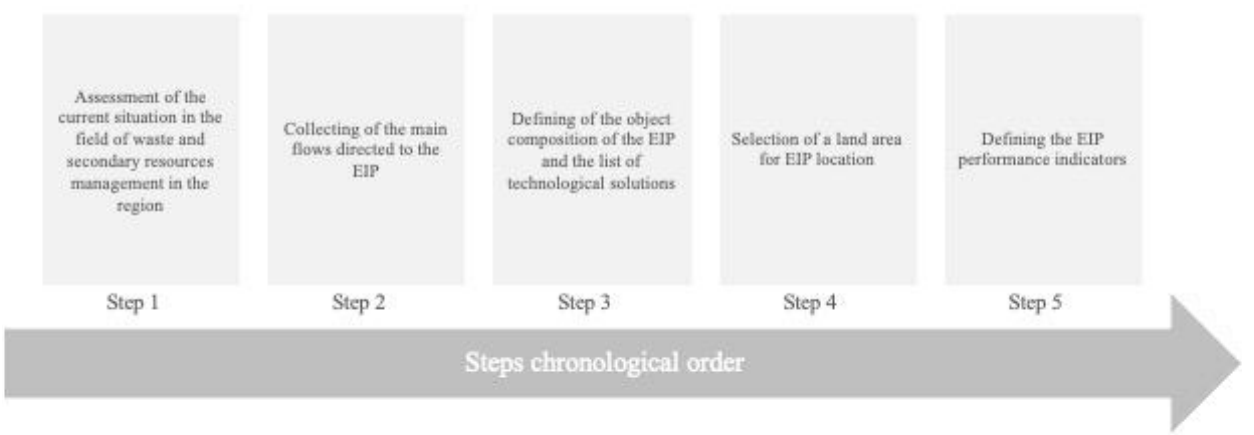

Fig. 2: Schematic Diagram of EIP guide

\section{RESULTS AND DISCUSSION}

\section{The EIP Methodology}

The entire process is viewed as an algorithm accelerator, allowing for the rapid identification and analysis of relevant
IS opportunities (Fig. 3). Each individual step's methodology, as well as the required inputs and expected outputs, are detailed below.

Step 1 -Assessment of the current situation in the field of waste and secondary resources management in the region

Table 1: Examples of Eco-Industrial Parks implemented on the principles of industrial symbiosis in the world

\begin{tabular}{|c|c|c|c|c|c|c|c|}
\hline 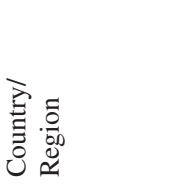 & 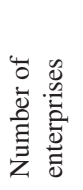 & 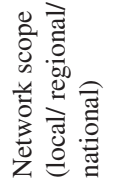 & 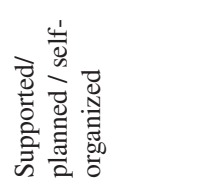 & 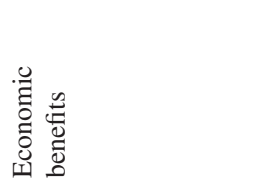 & 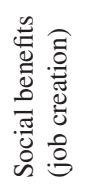 & 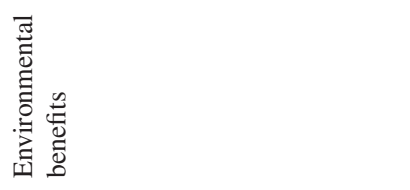 & 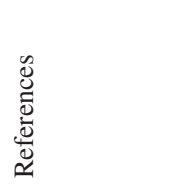 \\
\hline $\begin{array}{l}\text { Denmark/ } \\
\text { Kalundborg }\end{array}$ & 9 & Regional & Self-organized & No data & 4614 & $\begin{array}{l}\text { Waste Prevention (1997): } \\
1 \mathrm{mln} \cdot \mathrm{m}^{-3} \text { of sewage sludge } \\
200,000 \text { tons of fly ash and boiler } \\
\text { slag } \\
80,000 \text { tons of sludge from gas } \\
\text { cleaning } \\
2800 \text { tons of sulfur } \\
300,000 \text { tons - annual reduction of } \\
\mathrm{CO}_{2} \text { emissions }\end{array}$ & $\begin{array}{l}\text { (Smirnova et } \\
\text { al. 2019) }\end{array}$ \\
\hline $\begin{array}{l}\text { Austria/ } \\
\text { Styrian recy- } \\
\text { cling network }\end{array}$ & 28 & Regional & $\begin{array}{l}\text { Self-organized, } \\
\text { supported }\end{array}$ & No data & 22943 & $\begin{array}{l}1 \text { mln tons of by-products } \\
\text { collected, } 780,000 \text { tons recycled, } \\
200,000 \text { tons thermal recycled. } \\
\text { Reached } 70 \% \text { waste recycling } \\
\text { rate, } \\
\text { reduced } 42 \% \text { of } \mathrm{CO}_{2} \text { emissions, } \\
25 \% \text { of energy resources are } \\
\text { renewable }\end{array}$ & $\begin{array}{l}\text { (Smirnova et } \\
\text { al. 2019) }\end{array}$ \\
\hline $\begin{array}{l}\text { Finland/ } \\
\text { Harjavalta }\end{array}$ & 13 & local & self-organized & No data & 1000 & $\begin{array}{l}\text { Waste utilization rate }-81.8 \% \text {. } \\
351 \text { tons/year of energy waste } \\
181 \text { tons/year of metal waste } \\
124 \text { tons/year of hazardous waste } \\
15 \text { tons/year of paper waste } \\
16 \text { tons/year of MSW }\end{array}$ & $\begin{array}{l}\text { (Cooperation } \\
\text { Fostering } \\
\text { Industrial } \\
\text { Symbiosis } \\
\text { Market 2018) }\end{array}$ \\
\hline $\begin{array}{l}\text { South Korea, } \\
\text { Ulsan Mipo, } \\
\text { and Onsen } \\
\text { Industrial } \\
\text { Park }\end{array}$ & 1000 & Local & $\begin{array}{l}\text { Supported, } \\
\text { planned }\end{array}$ & $\begin{array}{l}\text { US\$ } 65 \text { million.year }{ }^{-1} \\
\text { from selling by-prod- } \\
\text { ucts and waste for re- } \\
\text { cycling purposes. } \\
\text { US } \$ 78.1 \text { million.year } \\
{ }^{1} \text { from energy and ma- } \\
\text { terial savings (in 2016) }\end{array}$ & 35 & $\begin{array}{l}\text { saved } 279,761 \text { tons of oil equiva- } \\
\text { lent in energy use } \\
\text { reduction of } 665,712 \text { tons of } \mathrm{CO}_{2} \\
\text { emissions and } 4052 \text { tons of toxic } \\
\text { gases during } 2005-2016 \\
79,357 \text { tons of water and } 40,044 \\
\text { tons of by-products and waste } \\
\text { were reused }\end{array}$ & $\begin{array}{l}\text { (World Bank } \\
\text { 2021) }\end{array}$ \\
\hline
\end{tabular}




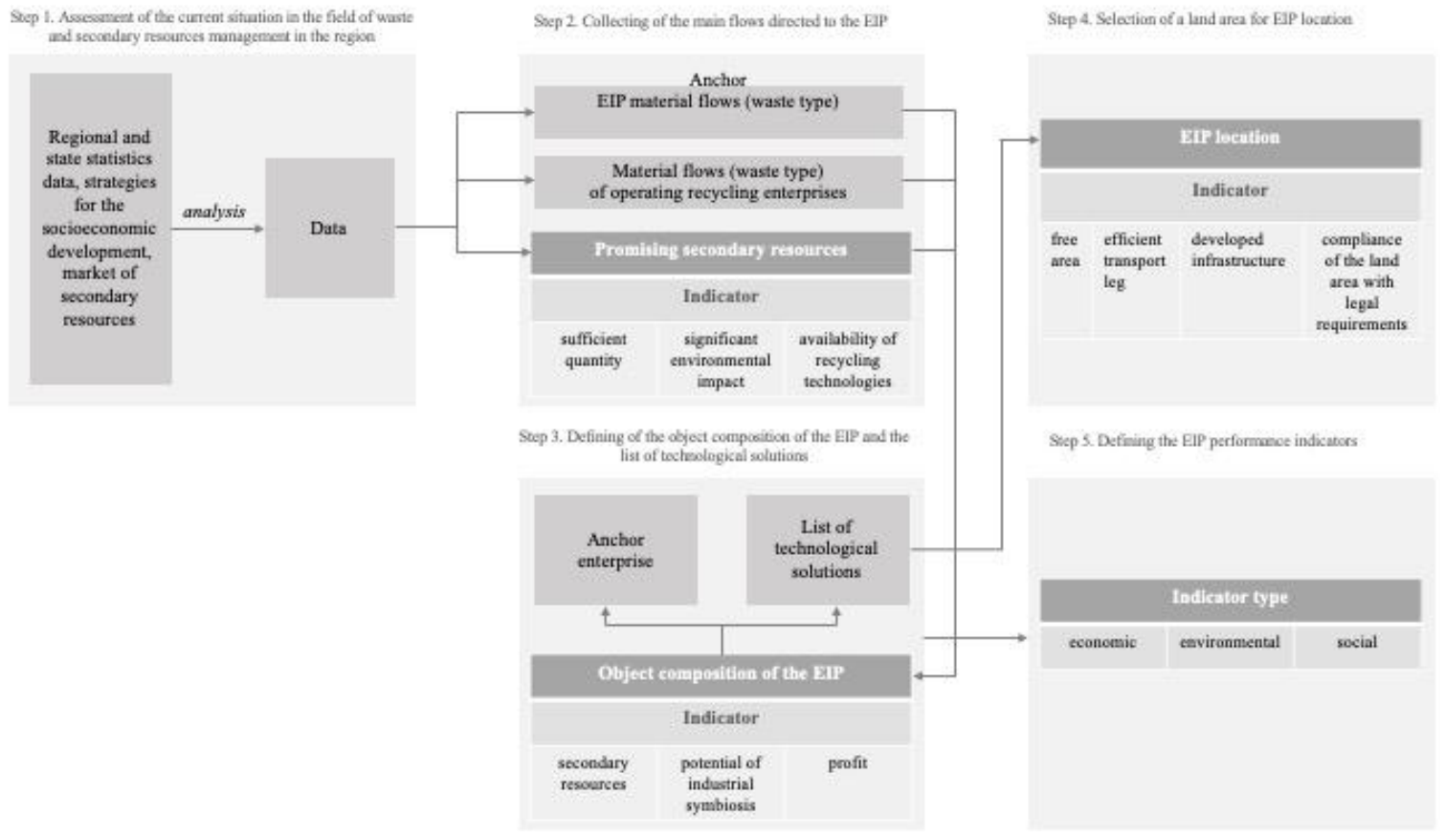

Fig. 3: EIP organization methodology

Input data analysis is the cornerstone of creating an EIP in a given region. This stage envisages evaluation of all available data on waste management in the region and its bordering regions; regional and national statistical accounts; data from environmental reference guides and databases; strategies for aerial and socioeconomic development; strategies for the development of certain industries; and marketing research reports on secondary resources markets.

These activities provide information on the following:

- amount of municipal solid waste (MSW) and industrial waste generated in the region;

- presence of the facilities for treatment, recycling, and landfilling of waste, if any, and the rate of capacity utilized;

- number of prospective sites for collecting, recycling, and decontamination and their location;

- Options for the development of industrial symbiosis;

- Opportunities for the interregional collaboration;

- Problems in waste management in bordering regions.

This set of data is the baseline for the next step.

\section{Step 2 -Collecting the main flows directed to the EIP}

At this stage, the analysis focuses on raw material flows of the potential EIP, including MSW, industrial waste, and prospective secondary resources to be probably generated during EIP operations including waste sorting and waste recycling.

The criteria for the selection of prospective secondary resources include their sufficient weight or volume; significant environmental impact; and the availability of recycling technologies.

The design of an EIP project requires drawing a plan to combine enough physical resources to enable reaching target rates of recycling and producing a strategy for collecting such resources.

A prospective increase in estimated capacity due to a possible increase in future waste flows resulting from interregional interaction or the elimination of objects of accumulated environmental damage, among other causes, must be considered in addition to the forecast average level of material flows towards a planned EIP.

Step 3 -Defining the object composition of the EIP and the list of technological solutions

Following the creation of the EIP's list of material resources, one must then create a list of technological solutions for the treatment, recycling, and decontamination of industrial and municipal waste/secondary resources to use in the manufacturing process. The analysis and marketing for the output based on secondary resources must be the following step. 
Selection of technologies requires envisaging the interconnectivity of technologies for the realization of symbiotic industrial connections between industrial facilities.

Technologies for treatment, recycling, and decontamination of industrial and municipal waste/secondary resources shall meet the following requirements:

- waste generated within the EIP operations process shall be safe or present minimal risks to the environment and human health;

- most of the waste shall be returned to the production cycle or must be securely disposed of as environmentally safe objects;

- the amount of landfilled waste must be minimized.

\section{Step 4 - Selection of a land area for EIP location}

The composition of the prospective EIP objects defines the requirements for the land area to locate the EIP. Its selection is a standalone task that also needs a multifactor approach.

The main criteria for the selection of a land area for EIP include:

- available area;

- effective transportation leg, from the source of waste generation through the waste storage places to the recycling and utilization facilities;

- suitable infrastructure (water supply and removal, energy and thermal power supply, good surface transport network);

- the land area's compliance with the current regulations and demands.

Other meaningful factors are the potential for the development of neighboring urban and rural communities, their functional zoning and development pattern, utility and transport infrastructures, rational management of natural resources, and environmental protection. It's essential to consider the efficient material sources while deciding where to locate EIPs. As a result, it is vital to select places with the maximum concentration of material flow sources, as well as factors affecting the region's development, such as physiographic, socioeconomic, transportation, and logistical.

EIPs' infrastructure is built in accordance with legislation governing industrial and technological infrastructure, operational profiles, and material and energy inputs.

The design of EIPs and implementation plans for innovative solutions shall account for reliability, ease of use, and the operational and maintenance efficiency of infrastructural facilities, as well as their reorganization and reconstruction, to ensure sustainable cost efficiency and the opportunity for technical upgrades.

There is the option to use economically and technically viable decentralized facilities.

In the design of an EIP, the transport and utility infrastructure shall ensure the following:

- possibility for the cooperation between utility facilities such as water supply and wastewater disposal, power and heating and gas supply, communications, etc.;

- interaction between industry facilities;

- transport links between urban and rural communities;

- separation of cargo and passenger traffic, the building of parking areas and networks of walkways and bicycle lanes;

- rational organization of pedestrian and automobile traffic towards workplaces, minimization of distances from operation support infrastructure.

\section{Step 5 -Defining the EIP performance indicators}

At this stage, we apply specially designed performance indicators to assess the efficiency of the EIP project in three main aspects, environmental, economic, and social.

As the key part of the circular economy, an EIP primarily aims at creating closed-loop supply chains to maximize the return of waste and secondary resources to new production. This approach enables efficient preservation and augmentation of natural resources and streamlining production processes, increasing resource and energy efficiency, which helps to scale down environmental problems and improve the region's economic efficiency and sustainability. Symbiotic connections between EIP participants allow addressing a number of diverse tasks as follows:

- reducing landfill areas;

- reducing emissions, dumping, and generation of waste;

- reducing energy and material costs;

- increasing resource and energy efficiency;

- returning secondary material resources to the production cycle and reducing consumption of natural resources;

- strengthening climate resilience by reducing greenhouse gas emissions from landfills;

- boosting capex efficiency while reducing operating costs;

- creating new jobs;

- raising the quality of life, also by improving environmental and economic conditions;

- supporting the region's transition to the development in the circular economy model. 
Below are the results of the evaluation of the described methodology applied to the organization of an EIP in the Voronezh Region of the Russian Federation.

\section{Case Study}

Voronezh Region, located in the Central European part of Russia, has an area of 52,216 sq.km, with a population of 2.4 million. The region comprises eight administration clusters: Voronezhsky, Liskinsky, Rossoshansky, Bogucharsky, Paninsky, Buturlinovsky, Borisoglebsky, and Kalacheevsky. The climate is continental. Economically, the region focuses on agriculture, industrial manufacturing, and construction. The main sources of waste generation are manufacturing facilities, MSW and food production, animal farms, and agricultural farms. Combined, they account for $4 / 5$ of the region's total industrial output. Leaders by waste generation in Voronezh Region are animal farms, sugar factories, and vegetable processors (The Strategy of Socio-Economic Development of the Voronezh Region 2018).

Step 1 - Assessment of the current situation in the field of waste and secondary resources management in the Voronezh Region

\section{The amount of MSW generation}

According to the waste inventory register of the Voronezh Region, the Voronezhsky inter-municipal cluster generates the greatest amount of waste, standing at 755.5 thousand tons ( $66 \%$ of the total in Voronezh Region), due to a significant concentration of population in the Voronezh agglomeration and a higher level of industrial and business activity. In each of the other seven inter-municipal clusters of the Voronezh Region, the amounts of annually disposed of MSW are meaningfully lower (Voronezh waste management system 2016).

\section{Waste disposal facilities}

There are 30 facilities on the list of waste disposal sites in the Voronezh Region. Over 80\% (24 facilities) are landfills. 17 of them deal with MSW and seven deal with industrial waste. Six facilities are dumpsites.

The majority of MSW landfills in the Voronezh Region are located in the Voronezhsky inter-municipal cluster. The capacity of landfills (filled with wastes) in the Voronezh Region ranges from $14 \%$ up to $115 \%$.

\section{MSW treatment facilities}

The sites for MSW treatment in the Voronezh Region are waste sorting facilities, five are in operation and are located in the Voronezhsky cluster (Novosumansky and Semilukinsky Districts), Borisoglebsky cluster (Povorinsky District), and Rossoshansky cluster (Rossoshansky District) (Voronezh Waste Management System 2016).

\section{Waste recycling facilities}

These are concentrated mainly in the Voronezhky cluster, in the City of Voronezh, and recycle all fractions of MSW.

\section{Interregional co-operation}

To assess the options for interregional collaboration in the operation of an EIP, we analyzed waste management systems in neighboring regions. Voronezh Region borders the Lipetsk, Tambov, Volgograd, Belgorod, Kursk, Rostov, and Saratov Regions. This analysis helped to define prospective districts from which waste (secondary resources) flows could be directed to the Voronezh EIP. Selection criteria included geographical proximity to the Voronezh Region and the absence of facilities for treatment, recycling, decontamination, and landfilling of MSW. The authors advise directing MSW flows from Terbunsky, Khlevensky, and Umansky Districts of Lipetsk Region as well as from Rovensky District of Belgorod Region (Belgorod Waste Management System 2016, Lipetsk Waste Management System 2019).

\section{Industries and industrial waste}

The industrial sector of the Voronezh Region is dominated by agriculture (The Strategy of Socioeconomic Development of the Voronezh Region 2018). As of 2018, the breakdown of industrial waste by volume in the Voronezh Region was as follows:

- food production - 3,810.23 thousand tons;

- animal farms waste - 2,852 thousand tons;

- mineral fertilizer production - 287.33 thousand tons.

Voronezh Region has no facilities for demercurization. Being a major logistical hub, Voronezh is the main producer of mercury-containing waste, while also accumulating the residue of such type delivered from other municipalities. It handles redirection of waste for decontamination outside of the region: to Moscow and the Regions of Moscow, Kursk, Ryazan, and Ulyanovsk.

The results of the analysis of the current situation in waste management in the Voronezh Region and bordering regions are presented in Table 2.

The Voronezhsky cluster is the primary source of MSW in the Voronezh Region. In Semiluksky Municipal District, there are three garbage disposal sites, facilities for recycling all MSW fractions, and a waste sorting facility with a used capacity of 440 thousand tons.year ${ }^{-1}$ (Voronezh Waste Management System 2016). The MSW sorting plant has a design capacity of 900 thousand tons.year ${ }^{-1}$.

Step 2 -Collecting the main flows directed to the EIP

We believe that recycling potential secondary resources 
such as scrap paper, plastic trash, and scrap glass have the most potential.

The establishment of a chain of interactions from waste generation to the manufacturing of products from waste and secondary resources is an example of how the methodological approach to the formation of material flows can be used to the EIP. (see Table 3).

Agriculture has the highest industrial load in Voronezh Region. Organic waste, manure, and food producers' waste could be generated by producers of meat, sugar, oils, fats, canned vegetables, and fruits, etc.

\section{Step 3 -Defining the object composition of the EIP and the} list of technological solutions

The agricultural sector defines the base for the prospective EIP. We advise building a complex for composting organic waste that would act as the anchor facility of the EIP. Produced compost shall be used for reclamation (remediation) of full landfills and unauthorized dumps. In the future, the complex may be converted to generate energy for the construction of other facilities within the EIP. Based on the analysis in steps one to three, we propose locating two sites of the Voronezh EIP in the Semiluksky and Rossoshansky districts. The proposed composition of the EIP by the example of Semiluksky District is presented in Fig. 4.

\section{Step 4 - Selection of a land area for EIP location}

The assessment based on our methodological approach resulted in the selection of two sites for the creation of the EIP:

- in Semiluksky District, with the area of 30.88 hectares and the developed infrastructure in the distance of 1.7 $\mathrm{km}$ from the MSW sorting plant;

- in Rossoshansky District, with an area of 4.6 hectares and the developed infrastructure in the distance of $3 \mathrm{~km}$ from the MSW sorting plant.

\section{Step 5 - Defining the EIP performance indicators}

The evaluation of the efficacy of the EIP activities was facilitated by the identification of three areas and the development of specific and quantitative performance indicators for each of them (Table 4).

The cornerstone of industrial symbiosis, according to leading Russian and worldwide specialists in the circular economy, is established by the combination of resource exchange between companies, recycling of secondary resourc-

Table 2: The results of data analysis.

\begin{tabular}{|ll|}
\hline Waste generation & Voronezh cluster 755.5 thousand tons (65\% of the total education in the Voronezh Region) \\
\hline Waste disposal facilities, percentage of filling & Only 30, of which 14 are 115\% filled \\
Current MSW recycling facilities & $\begin{array}{l}\text { Recycling companies of all MSW fractions } \\
\text { (Voronezh cluster) }\end{array}$ \\
Planned waste recycling facilities & 8 \\
MSW processing facilities & 7 waste sorting facilities \\
Interregional interaction & Belgorod region (Rivne district) \\
& Lipetsk region (Terbunsky, Khlevensky, and Umansky districts) \\
Industrial waste & Waste from food production, farm animal waste, garden waste, mercury lamps, used oils \\
\hline
\end{tabular}

Table 3: Chains of relationships from waste generation to the final consumer of products.

\begin{tabular}{|c|c|c|c|c|}
\hline $\begin{array}{l}\text { Material flow } \\
\text { (waste type) }\end{array}$ & Waste recycling company & Secondary resources & Recycled products & $\begin{array}{l}\text { Potential consumers of } \\
\text { secondary resources }\end{array}$ \\
\hline Plastic waste & $\begin{array}{l}\text { Voronezh-Polymer LLC } \\
\text { LLC Polymer-Chernozemye } \\
\text { LLC "Contact" } \\
\text { LLC "Management Company } \\
\text { Region-Resource" } \\
\text { Voronezhvtorma LLC }\end{array}$ & $\begin{array}{l}\text { Crusher, agglomerate, } \\
\text { granules, flex }\end{array}$ & $\begin{array}{l}\text { Polyethylene film, garbage bags, } \\
\text { polyethylene granules, LDPE film, } \\
\text { plastic packaging }\end{array}$ & $\begin{array}{l}\text { Producers of PET bottles and } \\
\text { other plastic packaging, bris- } \\
\text { tles for cleaning equipment, } \\
\text { building materials }\end{array}$ \\
\hline Paper waste & $\begin{array}{l}\text { Eco Liner LLC } \\
\text { LLC "Kharti" } \\
\text { LLC "Kivo Market" } \\
\text { LLC "KartonChernozemye" }\end{array}$ & $\begin{array}{l}\text { Pressed sorted waste } \\
\text { paper, cellulose wool }\end{array}$ & $\begin{array}{l}\text { Sanitary and hygienic products, } \\
\text { corrugated board, cardboard }\end{array}$ & $\begin{array}{l}\text { Producers of cardboard, san- } \\
\text { itary products }\end{array}$ \\
\hline Scrap glass & $\begin{array}{l}\text { "Branch of LLC RASCO" } \\
\text { Voronezh glass container plant" } \\
\text { LLC "Sferastek" }\end{array}$ & $\begin{array}{l}\text { Sorted scrap glass } \\
\text { Processed containers }\end{array}$ & $\begin{array}{l}\text { Foam glass, fiberglass, glass crystal } \\
\text { materials, road marking materials } \\
\text { Reusable packaging }\end{array}$ & $\begin{array}{l}\text { Producers of glass contain- } \\
\text { ers, building materials } \\
\text { Producers of drinks, food }\end{array}$ \\
\hline
\end{tabular}




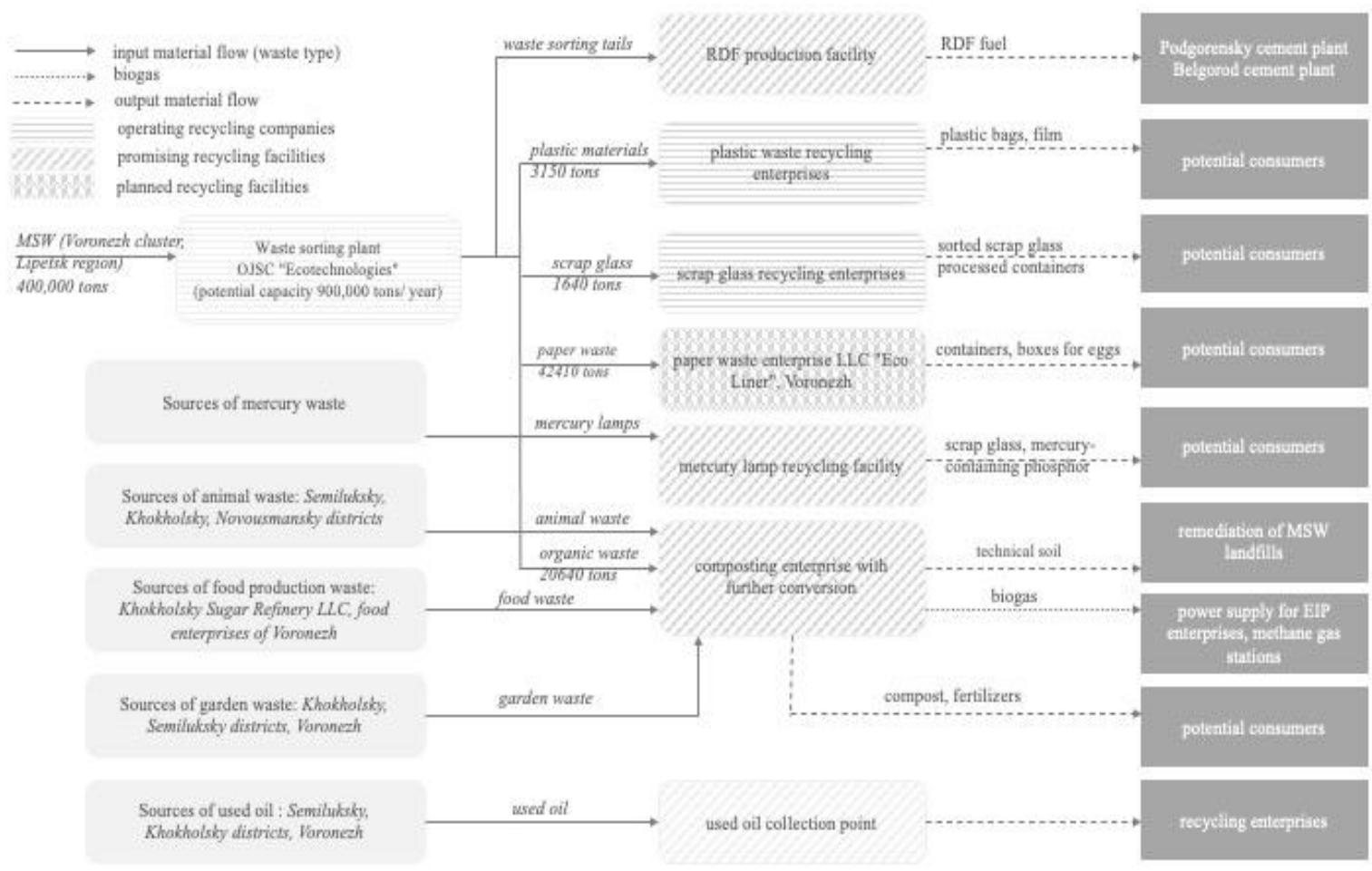

Fig. 4: Model of the object composition of the EIP in the Semiluksky district

es, involvement of many enterprises, and manufacture of competitive goods. The proposed methodological approach reflects this viewpoint.

The findings of the work on the EIP model's organization have been approved, and the Voronezh Region Administration is considering them further. The approach is planned for possible replication in other regions.

Thus, using the Voronezh Region of Russia as an example, the five stages of EIP organization proposed in the study make it possible to close waste streams to recycling firms operating and developed within the eco-industrial park.

Table 4: Assessment of compliance with the criteria for sustainable development of performance indicators of the EIP

\begin{tabular}{|ll|}
\hline Indicator type & Indicator \\
\hline Economic & Increasing share of secondary resources usage in production \\
& Increasing investments in waste recycling and recovery and use of secondary resources \\
& Decreasing fees for the negative impact of waste disposal \\
& Decreasing operating costs \\
Environmental & Reducing landfill disposal \\
& Increasing waste recycling rate \\
& Decreasing emission of greenhouse gases \\
& Increasing the secondary resources recovery rate \\
& Increasing volume of production using waste and secondary resources \\
Improving resource and energy efficiency & Increasing number of facilities implementing the best technologies available \\
Increasing public satisfaction with the quality of the environment \\
Increasing the number of jobs involved in waste recycling and using secondary resources
\end{tabular}


This is in line with the primary goals of establishing an ecoindustrial park: improving resource efficiency and reducing landfill waste disposal.

\section{CONCLUSION}

The authors presented a methodological approach based on classification and algorithmization of operations that must be followed to create an Eco-Industrial Park. In steps One and Two, initial data is processed to evaluate and calculate material flows to the prospective EIP. In step 3, the data collected and processed is used for designing the project composition of the EIP and choosing the required technological solutions. Step four sets the requirements for the land area and infrastructure for the EIP. In the final step, five performance indicators of the EIP are defined. This approach aims at delivering a comprehensive solution to the problem of waste management and reuse of secondary resources in regional economics. Implementing this technology to construct an EIP in the Voronezh Region could help to streamline trash flows and raise recycling rates by increasing capacity, all while lowering the negative environmental impact of waste landfilling. Implementing the circular economy in the appropriate region is one of the EIP's core ideas.

This paper gives a general outline of the methodology for the Eco-Industrial Parks organization. The authors continue refining the approaches to develop more detailed operations at each step and produce template technological solutions for EIPs.

\section{REFERENCES}

Albino, V., Yazan, D.M. and Romano, V.A. 2016. The design of industrial symbiosis: An input-output approach. J. Cleaner Prod., 129: 537-547.

Alejandro, M., Gómeza, M., Gonzáleza, F.A. and Bárcena, M.M. 2018. Smart eco-industrial parks: A circular economy implementation based on industrial metabolism. Resour. Conserv. Recycl., 135: 58-69.

Ayres, R.U. and Simonis, U.E. 1994. Industrial Metabolism: Theory and Policy. In: Ayres, R.U. and Simonis, U.E. (eds), Industrial Metabolism: Restructuring for Sustainable Development. United Nations University Press, Cham, Switzerland, pp.3-20.

Chertow, M.R. 2007. "Uncovering" industrial symbiosis. J. Ind. Ecol., 11(1): 11-30.

Chew, I.M.L., Leong, Y.T., Lee. J.Y., Tan. R.R. and Foo, J.J. 2017. Multi-objective optimization for resource network synthesis in eco-industrial parks using an integrated analytic hierarchy process. J. Cleaner Prod., 143: 1268-1283.

Cooperation Fostering Industrial Symbiosis Market 2018. Potential, good practice, and policy actions: Final report. Available at: URL: http:// trinomics.eu/project/industrial-symbiosis (accessed 20 April 2021).

Côté, R.P. and Hall J. 1995. Industrial parks as ecosystems. J. Cleaner Prod., 3: 41-46.

Côté, R.P. and Cohen-Rosenthal, E. 1998. Designing eco-industrial parks: A synthesis of some experiences. J. Cleaner Prod., 6: 181-188.

Ernest, L.A. 1995. The Eco-Industrial Park: A Business Environment for a Sustainable Future. Paper presented at Conference on Designing, Financing and Building the Industrial Park of the Future," sponsored by the U.S. EPA, Research Triangle Institute, and the University of California at San Diego, San Diego, May 4-5.

Fischer-Kowalski, M. 1998. Society's metabolism: The intellectual history of material flow analysis, Part I, 1860-1970. J. Ind. Ecol., 2(1): 61-78.

Hein, A.M., Farel, R., Jankovic, M. and Yannou, B. 2016. A data- and knowledge-driven methodology for generating eco-industrial park architectures. In ASME 2016 International Design Engineering Technical Conferences and Computers and Information in Engineering Conference, Charlotte, North Carolina, USA, 21-24 August 2016, pp. 1-12.

Kiseleva, S.P., Smirnova, T.S. and Maryev, V.A. 2018. Transition to a Circular Economy: A Way to Improve the Ecological Situation In Russia. In Priority And Promising Directions Of Scientific and Technological Development of the Russian Federation, Materials from the Seminar of the 1st Russian Scientific and Practical Conference, Moscow, Russian Federation, 11 April 2018, pp. 240-245.

Leeuwen, M.G., Vermeulen, W.J.V. and Glasbergen, P. 2003. Planning eco-industrial parks: An analysis of Dutch planning methods. Bus. Strategy Environ., 12: 147-162.

Mashukova, B.S. 2016. Basic principles of a circular economy. Euro. Sci., 7: $14-16$

Neves, A., Godina, R., Azevedo, S.G., Pimentel, C. and Matias J.C.O. 2016. The potential of industrial symbiosis: Case analysis and main drivers and barriers to its implementation. Sustainability, 11(24): 1-68.

Belgorod Waste Management System 2016. On approval of the territorial waste management system, including solid municipal waste, in the Belgorod egion (2016) Regulatory Act. Available at: URL: http://belgkh.ru/ media/site_platform_media/2020/2/28/postanovlenie-pravitelstva-belgorodskoj-obl-ot-26092016-350-pp.pdf (accessed 20 April 2021).

Voronezh Waste Management System 2016. On approval of the territorial waste management system, including solid municipal waste, in the Voronezh Region. Regulatory Act. Available at: URL: https://docs.cntd. $\mathrm{ru} /$ document/453149000 (accessed 20 April 2021).

Lipetsk Waste Management System 2019. On approval of the territorial waste management system, including solid municipal waste, in the Lipetsk Region. Available at: URL: http://ekolip.ru/territorialnaya-skhema-obrashcheniya-s-otkhodami.php?clear_cache=Y (accessed 20 April 2021).

Pakhomova, N.V., Richter, K.K. and Vetrova, M.A. 2017. Transition to the circular economy and closed supply chains as a factor of sustainable development. J. Bul. St. Pet. State Univ., 33(2): 244-268.

Park, H.S. and Behera, S.K. 2014. Methodological aspects of applying eco-efficiency indicators to industrial symbiosis networks. J. Cleaner Prod., 64: 478-485.

Skobelev, D.O. 2020. Formation of the infrastructure of resource-technological transformation of industry. Eco. Sust. Develop., 1(41): 162-167.

Smirnova, T.S., Maryev, V., Guz, L. and Mankulova, J. 2018. Industrial symbiosis as an instrument of sustainable development in the modern world. Interdiscip. Sci. Pract. J: Ecol. Ind. Prod., 3: 64-68.

Smirnova, T.S., Evtukhov, V.L. and Maryev, V.A. 2019. Analysis of the World Experience: The Organization f Eco-Industrial Parks and the Implementation of the Principles of the Circular Economy. INFRA-M., Cham, Switzerland

The Strategy of Socio-economic Development of the Voronezh Region. 2018. Regulatory Act: For the Period Up to 2035. Available at: URL: https:// docs.cntd.ru/document/550300779 (accessed 20 April 2021).

Tiejun, D. 2010. Two quantitative indices for the planning and evaluation of eco-industrial parks. Resour. Conserv. Recycl., 54: 442-448.

Tyrganova, A.A. and Makhashkeeva, A.Y. 2014. Circular economy as a new model of the world economy: Foreign experience and Russian practice. Eco. Sci. Appl. Res., 18(22): 301-304.

World Bank. 2021. International Framework for Eco-Industrial Parks v.2. World Bank, Washington, DC.

Zhou, L., Pang, M., Sikorski, J., Garud, S., Kleinelangshorst, M., Karimi, I. and Kraft, M. 2017. System development for eco-industrial parks using ontological innovation. J. Energy Procedia, 105: 2239-2244. 